\title{
Analysis of Pedagogical Situations to Promote Inclusive Education
}

\author{
France Dubé, Marie-eve Gadbois, France Dufour \\ Université du Québec à Montréal, Canada
}

\begin{abstract}
The purpose of this study was to assist school personnel in planning and organizing the integration of students with special needs. Group interviews and analyses of pedagogical situations have helped implement and document the progressive integration of students with disabilities from special classes into regular classes as well as increase the level of collaboration among all the parties involved. This article will focus on the analysis of the conditions that promote inclusion. It will analyses the best collaboration practices to be put in place and a procedure which entails exchange meetings, listening, and understanding. In addition, it will focus on the creation of a bond of trust among the various members of the personnel including the school management. Results show that the school staff, as a whole, wants to ensure that all students are given the best opportunities to achieve educational success and this goal is kept in mind when they prepare integration. Furthermore, teachers are concerned about generating a positive perception about inclusion among their peers who teach in regular classrooms.
\end{abstract}

\section{Introduction}

This study originally aimed at accompanying school staff in the organization and planning for integration while describing the collaborative arrangements that contribute to the organization of educational services. In this article, we shall present the results we obtained after the first year of project implementation in two elementary schools. We will specifically examine the results necessary to achieve our two first research objectives: implement a collaborative tool that favors the integration into regular classes and support critical thinking, get engaged in collective questioning, and share contextualized solutions in a framework for the analysis of pedagogical practices.

\section{Problem}

For 30 years, school integration has been promoted in Quebec. Despite a quick development from 1970 to 1980, a stagnation can however be observed during the last years [1]. Additionally, in spite of the implementation of resolutely inclusive educational policies [2], both school systems, special education and regular education are still present in Quebec schools, and it is still possible to find in one school the coexistence of both specialized and regular classes. School integration of students with disabilities or special needs, can be situated on a continuum of actions and organization of services [3], which is sometimes put into place gradually, to then progress towards complete inclusion. In Quebec, the percentage of students integrated into regular classes has increased during the last ten years from a $56,4 \%$ in $(2001-2002)$ to a $74,1 \%$ in (20152016 ), to reach an $84,9 \%$ of students with disabilities or special needs being integrated into regular classes at elementary schools [4].

Our approach is part of a reflection on school organizational models in the wake of a social and political will to include all elementary school students in the regular school system while improving their perseverance and success. Since 1999, the Quebec Policy on Special Education has aimed to "Placing the organization of educational services at the service of students with special needs by basing it on the individual evaluation of their abilities and needs, by ensuring that these services are provided in the most natural environment for the students, as close as possible to their place of residence, and by favoring the students' integration into regular classes" [5] (p. 5). Regardless of the Organization of Educational Services [6], a lot of questions still have no answers for those schools who would like their students that are currently attending special classes be integrated into regular classes.

School principals have more responsibilities but also more latitude regarding the organization of educational services in their schools [7]. And although a Governing Board is established at each school to endorse educational choices each year, the elected members who sit there are not required to consult recent research data to support their decisions. As a result, the way schools and school boards are administrating and organizing their educational services to make available the resources needed for students' success vary significantly from one school to another [8].

Since 2009, Quebec school boards have had to establish partnership agreements to define the context in which they contribute to their students' success and perseverance. However, the organization of services is often orchestrated according to the 
available financial and human resources, which leads to significant disparities from one school to another [9]. In addition to the main orientations proposed by the ministry guideline documents, little is known about the organizational models implemented locally in Quebec school boards [10]. Besides, even though we now advocate "an organization of educational services taking into account each student's needs" [6] (p.1), there are still many organizational changes and challenges gaps that need to be addressed collectively.

Several school boards have instituted a policy on the organization of educational services on their territory. These policies consider that the educational integration of students with special needs must be the first service to be considered. Yet, students' perseverance and success remains a constant concern of the school system and collaborative practices are already planned during the development and evaluation of the intervention plan; however, they amount to the constitution of ad hoc committees [11]. In a context where school boards are responsible for the organization of the services that are, in turn, decentralized to schools, the result is a great disparity of the services offered, and both systems, special and regular, still cohabit to this day within the same school. Faced to this reality we pose the following question: How can elementary schools implement collaborative arrangements that will facilitate the integration of students with disabilities from special to regular class?

\section{Reference framework}

As several studies link collaboration and the quality of teaching with students' success as well as with a successful integration of special needs students [12], we have decided to analyze the pedagogical practices and situations in the context of the integration of students with special needs.

Previous research has shown that the teachers' level of collaboration with each other would have an impact on students' success at school [13] [14]. Studies have shown that there are effective collaborative projects between special schools and regular schools that can be put in place for all the students' benefit [15] as well as between the school and the outside services [16] or even including health and social services in schools, comprising the families [17].

This collaboration is essential [18] and "All of them-administrators, teachers, complementary educational services personnel and support staffmust work together to create optimal teachinglearning conditions. In so doing, they have to go beyond individual competencies and create collective competency." [6] (p.7). This collaboration can be established among all those working with the students [19] during both formal and informal meetings [20] and it could contribute to favor the success of students with special needs.

In a study aimed at understanding the attitudes of elementary school teachers regarding the conditions facilitating inclusive education, in order to better understand their impacts [12], emphasized the importance of a good collaboration among teachers. The results show that $82 \%$ of the teachers who practice an integration model and work at inclusive schools believe that collaboration among the colleagues would improve the education offered to all students in their classrooms. This collaboration helps maintain a consistency in the approaches and interventions for students with special needs.

In order to support school staff in their professional development as well as to collaborate for the implementation of actions that make integration easier, different group practice analyses, sometimes in the form of group consultation [21] can be implemented at schools. These procedures encourage exchanges between the members of the same school and even from different school environments. In addition, they could become a place of exchange and analysis allowing teachers to explain, elaborate, clarify, re-examine, and sometimes even redefine their practices [22].

The establishment of procedures for group practice analysis would disclose elements of practice that can contribute to the inclusion of students. The aim of such procedures is to collectively analyze pedagogical situations. In a school environment, the school staff can debate about different obstacles they have encountered and anticipate elements, concerns or even discuss observations they have made when integrating students from special into regular classrooms. A participant called the 'narrator' freely starts and shares with the group a situation he has experienced or that he is afraid of living during the integration of students from special classes. The rest of the participants listen to him and once the situation has been fully exposed and explained they may ask questions to the 'narrator' if they need to clarify certain aspects. Then, they collectively reflect and analyze the complexity of the situation in a space named 'critical conversations' [23] in [22], which we will call 'analysis of pedagogical situations'. This procedure ultimately aims to 'identify' practices, in order to induce "an opportunity, a space to rethink the relationships with the student, the class, the knowledge, but also with the colleagues, the institution" [22] (p.785). 


\subsection{Objectives}

The purpose of this study was to assist school staff in the planning and organization of the integration of students with disabilities into regular classes.

The specific objectives are:

1. Experiment with a collaborative procedure that promotes the integration into a regular class.

2. Support reflection, enter into a process of collective questioning and share contextualized solutions in the context of pedagogical practice analysis.

3. Describe the collaborative procedures put in place to promote the inclusion of students into regular classes.

In this paper, we will introduce the procedures conducted at a school board during the first year of research focusing more specifically on the findings aimed at achieving our first two objectives.

\section{Methodology}

This approach follows the adaptation of an integration protocol aimed at enhancing the cooperation among personnel during the transition from the special class to the regular class [24]. The protocol was proposed to all the schools of a school board and the participants in this study work at two elementary schools of the sector. Four regular class teachers, three special class teachers, three special education instructors, two school principals, a special need educational consultant, two researchers, and a research assistant (a doctoral student) participated in this project.

Two group interviews were conducted in October and December involving all the school members from both schools. The interviews aimed to collect data on organizational practices, inclusive practices, targeted students, involved actors, ongoing collaboration, effects observed in their students, challenges encountered as well as on the facilitators and obstacles. The outline of each interview included 15 questions and each group interview lasted around 2 hours 30 minutes.

A second phase of group interviews was conducted in both schools from January to March over a period of several weeks. These meetings allowed the analysis of some of the pedagogical situations encountered during the organization of the educational services placed with a view to integrating students into ordinary classes. Three halfday meetings were planned. The participants had been given the canvas for the analysis of pedagogical situations beforehand and were invited to reflect on a particular situation they had lived or apprehend that they wished to share with the group.
During these meetings, the participants were invited to adopt the role of 'narrator' in turn and on a voluntary basis; once their situation had been presented they received proposals from the other school actors. An external participant, a member of the research team that had no knowledge of the situation presented by the narrator played the role of the mediator in the exchanges. His role was to ensure that the interactions were respectful and neutral, nonjudgmental, and related to the situation that had been described, while he structured the discussion according to the time that had been allocated to each period of the analysis.

\subsection{Procedures}

The analysis of the situations was structured in five stages:

1. The narrator speaks and describes his situation in as many details as possible. Stating the facts and exposing his needs (10 minutes);

2. All the other participants can step in and ask questions to get more information and details. The person appointed as mediator must regulate the questions (there is no judgment or analysis of the situation at this stage: 3 minutes);

3. The narrator listens to the other participants without intervening. The participants formulate their hypotheses, their reactions, their personal experiences in relation with the situation exposed making no judgment whatsoever. The testimonials that have been shared are expected to help the narrator better understand his practices and respond to his needs (15 minutes);

4. The narrator verbalizes what he recalls from the analysis and makes an assessment of what has particularly helped him or her. The narrator also shares his reactions taking into account his initial needs and the proposals that have been offered ( 5 minutes);

5. The mediator gives each participant the opportunity to review the experience and tell what they retain from the situation (untimed).

Two or three situations were presented by different narrators and discussed in groups for a maximum of 40 minutes per situation analyzed. In order to have a wide range of situations, it was suggested that they could be presented by both regular and specialized classroom teachers. At the end of the school year, a few two-hour assessment meetings were held so that each school could present a summary of the results and key findings as well as to plan and prepare the second year of the project.

Verbatim records of the meetings and practice analysis were transcribed onto Word and then coded 
using NVivo 11 software. In total, considering only the 7 practice analysis, the analysis performed with the software generated 302 meaning units. The analysis plan included a coding by key nodes: collaboration, organization of services, students and school staff needs, integration conditions (facilitators and barriers). In this article, we present the results of the service organization analysis (69 coded meaning units).

It should be noted that ethical precautions have been taken to carry out this research. The anonymity of the participants and the confidentiality of the data have been preserved; all subjects participated in the study on a voluntary basis, with the option of withdrawing from the study at any time.

\section{Results}

As part of our research project, when the research team proposed to accompany the schools and their staff in the organization of services that would make integration easier, during the group meetings with both schools, the need of conducting the analysis of pedagogical situations emerged as a device to enhance collaboration, collective reflection and exchange expertise.

\begin{abstract}
The advantage of that is that we already have the expertise, I think. In fact, we have it here in the school itself. We have it on our workplace because we have people working in and coming from different environments, and, in fact, I consider it would be enough if we would have time to talk to each other. [M1_SO]
\end{abstract}

The data from the three groups and seven pedagogical situation analysis conducted in the two elementary schools were analyzed with a view to highlighting the organization of integration, the challenges and obstacles that could be faced, the facilitators perception, the actions to be put in place as well as preparing all the community so that the integration of the students could be done as smoothly as possible.

\subsection{Organization}

Since the students at the heart of this research have been schooled in special classes from their early childhood, the school staff studies carefully the special situation of each of them in order to better plan their integration process:

This year, I had a student. [...] He stood out in terms of his abilities, both academically and socially. Perfect.
$O K$. We prepare everything with the administration staff and the regular class teacher. We create the preconditions. [M3_SA1_S2]

[...]. This means that there is no hurry; you do not want to do it at haste. The decision was taken in a committee; it's something we've been planning for a year or two, which means we have observed the students in the other classes, and we say perfect, I think the student is ready for integration. For me, there is no hurry, none at all. We respect the student's rhythm which I believe is vital. We try to meet the student's needs. That's very important [M3_SA1_S2]

They also emphasize the importance of targeting the student's needs:

But the following questions have to be answered "Why do we want the integration?" "What are the needs we want to address?" [M3_SA_S2]

During the discussions, the educational advisor states the importance of taking the time to plan the integration and organizing the educational services that are going to be offered to the students and the teachers taking into consideration the specific learning needs of each student. She also stresses the need for anticipating the support other members of the school staff may require throughout the integration period:

We are talking about "students'
cases", not "unique profiles". We must
bear in mind that every child has his
own needs. There will always be
questions to which we will have no
answer, questions we cannot foresee,
it's unavoidable. It will always be
necessary to have discussions, as you
have them when you need them, as, for
example, when you have a tête-à-tête.
But certainly even if it's an informal
discussion, it is still well established,
the student's profile is done. I think it
would be helpful to answer many of
our questions. [M4_SA_S2]

In School 1, the team was willing to better observe the students in the classroom in order to support their integration and, if necessary, provide support. 
The next step could be to make up a grid ... What are the questions we ask ourselves?... or an observation grid, well it doesn't really matter how we call it. A grid that would pin point the minimal conditions required to be in a regular class. [M3_SA_S1].

Exchanges during the meetings concerned academic skills but also personal and social skills, in addition to the student's support needs so that he could gradually acquire more autonomy in order to ensure a successful transition during his integration into the regular class.

The student's support was also raised by a special class teacher at school 2:

\section{[...] A successful integration is also ... perfect, he is academically good. But what about his confidence, his esteem; will the student in question be able to ... find solutions to his problems without the presence of the adult? [...] It may be ok academically, but what about his social skills, and there is also the question of the proximity of the adult ... What if he can't progress without the proximity of the adult... [M3_SA1_S2]}

These questions lead them to better plan and support the student in the development of his social skills. The concern that the integration is a success for all the persons involved was also mentioned by a special class teacher. She emphasized the importance of the student being welcomed but she also remarked that it was essential that the regular teacher was willing to differentiate her teaching whenever necessary for the integration to be successful:

I understand what you want ... your credibility is at stake, you want it to be 'perfect', so that nobody's finger points you for anything, but the teacher must also be trusted, that she can 'handle' the differentiation... [M3_SA1_S2]

\subsection{Challenges}

Certain questions were raised by the school personal concerning the responsibilities associated with the students' support during their integration into regular classes. The group is under the teacher's responsibility, but the student is often accompanied by the special education technician (SET):

\begin{abstract}
[...] He has been integrated since grade 3 , since last year full-time. However last year he was still in charge of the special teacher. This year, he is just another student in the class ... [cross comments] this is since September.[M3_SA_S1]
\end{abstract}

Questions are also raised about the evaluation. We debate about the level of differentiation in the assessment of the students' competencies:

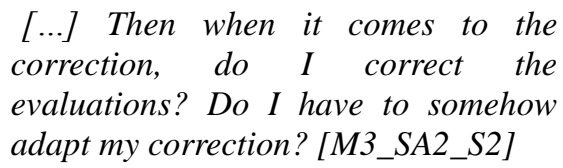

While were doing another situational analysis, the regular classroom teacher wonders who to call if the newly integrated student needs support:
Then, if something that I cannot manage happens during the day, do I call the SET assigned to the student? Or do I ask for help to the SET that is on the floor? [M3_SA2_S2]

A situational analysis leads participants to examine the role of the special education technician in the transition from the special class to the regular class:

...The special educator accompanied
the student for the first four to five
days. At the end of the fifth day,
"perfect, everything's ok, let me go."
And that's the way it's been until the
end of the year. I think it would be very
important to preserve the attachment.
The bond was always my class; he was
part of the [class-group number]
group. On the other hand, there was a
bond with the professor, the SET, and
all that, and when the time came to
prepare the report, the professor gave
me the marks and I completed the
report. So that she still belonged' to
me [M3_SAl_S2]

We also propose gradual removal of the special education personnel, so that the integration can evolve towards a total inclusion.

But gradually, so that it evolves towards a complete integration, all the special education personnel in charge of the student in question should gradually take a step back. That, I 
think, is very important. Thus, it requires some planning.[M3_SA1_S2]

The school personnel talk about the possibility of a gradual integration organized over two academic years, to go from a partial integration to full inclusion:

Why do you say that I don't know? I simply hesitate between part-time and full time. What would be better? What is better? ..., I would even consider integration over a two years' period. For example, I could have a student in grade 5 part-time, then after that in grade 6 completely full time. Because I think it takes these children longer to adapt, but that's my perception. [M3_SA2_S2]

The school personnel also mentioned that the students could participate progressively in regular class activities and then gradually increase the time until their complete integration:

\begin{abstract}
At the beginning of the integration, he can continue to dine with his classmates in the special class or even spend the end-of-day periods with them. Then, gradually, the student is completely integrated in the regular class for all the activities. [M4_SA_S2]
\end{abstract}

\subsection{Facilitators}

The personnel of school 2 notes that it is important to carefully plan the number of students per class so as not to exceed the maximum number of students per group. Furthermore, they state this condition is essential for the integration to be successful; the teacher-student ratio cannot be too high:

There is an important element we do not control. [...] the number of students in the class ... there is not much I can do about it. [...]but to unbalance the groups if anything at all [...] We have to start predicting class ratios in advance if we want to be able to do an integration. [M3_SA1_S2]

In order to make better planning and facilitate the transition to the regular classroom, school 1 has decided to plan student groupings for their integration:

\begin{abstract}
... in group 4-5-6, they all have potential for integration. In fact, they are all already integrated, either in a subject or, sometimes, they are even integrated full-time, just like [student's name], in order to be completely reintegrated the following year [M4_SA_S2]
\end{abstract}

\subsection{Obstacles}

The openness of the school community and its personnel to integration is a crucial element, and participants stressed that this openness needs to be developed. School boards and Quebec schools are in the process of moving towards an inclusive school. However, reluctance and obstacles remain. Some of our participants want integration to be viewed positively and they demonstrate a willingness to avoid negative perceptions in their schools, as negative perceptions could become barriers to the integration of students in the future:

\begin{abstract}
I think it's because [teacher's name] wants integration to become more and more accepted. Because reluctance can still be perceived; the teachers perceive integration as a ... surplus, we feel that it is more work. [...] And the more things progress, the more I see its magnitude. So I think that he wants it to be so perfect, to avoid that the following year we say no. Of course, I understand him. Because many regular class teachers are not really open to integration. [M3_SA1_S2]
\end{abstract}

\subsection{Welcoming the student}

An ordinary class teacher tells the group her reluctance and worries before welcoming a student who will soon be integrated into her regular class:

It worries me a bit because I have never integrated a child with ASD before. I have been given no training for doing so; In fact, I do not know this "clientele" and I would like to know it. Even if I am a person who believes they are well in their little "cocooning", as [name of the SET] said before. I think they are lucky to have that space and I would personally leave them there. But I realize ... I have understood after the intervention, why we want to integrate them to the regular classes, in fact, it is because of 
the society, life in the future ...[M3_SA2_S2]

The same teacher, who had talked about her apprehensions at the beginning of the project, then spoke of the positive aspects of integration, as she herself could perceive after the integration of a student in her class in January. She even observed positive effects for all the other students in her class:

I find this new student has a lot to give to the group. Seriously, he participates in class, it might be very naïve what he says, but it brings the children, the rest of the group, back. I find it really beautiful. [M4_SA_S2]

A special class teacher acknowledges that they organize awareness activities in all the school, something that could promote integration into regular classes:

And we do it every year all year round.

Thus, the month of autism, we promote autism in the classrooms. And I find it's important. [M3_SA1_S2]

Preparing for the integration and welcome of special needs students comprises planning and organizing the physical space.

Yes, we integrate them, but once it's done, ok we have 27 students now, and it's not only about having enough space in the classroom. Where do I place him? It may sound insignificant, but physically, what are his needs, can he be close to other students? The proximity to his peers ... can this be an obstacle? In fact, we are quite jammed in my class... [M3_SA2_S2]

\subsection{Implemented actions}

In order to support the continuum of actions leading to inclusion, the principal mentions that time has been allocated to the school personnel involved in it so that they can better plan and organize the educational services:

[...] and, in fact, it exceeds the money we have for meeting now. The money allocated comes from another budget, downright.
That's it. It's the equivalent of almost once per cycle that you can meet. I think it's a lot. [M3_SA_S2]

In this regard, the teachers explain that it is easier for them if they fix in advance the meetings dates and time to discuss integration issues. According to the school personnel of this community, bi-weekly meetings would be the ideal at the beginning of the integration to gradually increase the intervals between meetings to one every three or four weeks.

What I would personally like to see is that every two or three weeks, we would have a common time period that has been scheduled. And this period is there as part of my task and during that period, I meet [name of the special technician] for this student. I would like that. It would discipline me. It has to be part of my schedule. Even if we have nothing specific to say, we meet anyway. [M3_SA2_S2]

In order to support inclusion, this school board offers training given by special education pedagogical consultants, particularly for regular class teachers integrating students with special needs. In addition to these trainings, the pedagogical consultant offers support to the school, at the request of the regular classroom teacher. Other professionals (psychologists, speech therapists) are also present during the integration into the regular class. A principal says:

I would also like to tell you that we work hard with the professionals so that the school professionals can support you. That is to say that besides me, as I'm not here on a daily basis, well, you also have the psychologists, the speech therapists, etc. who are there to support you at any time. Because after having been working with us for several years they have a good knowledge of the "clientele". So, never forget that we have the chance of having professionals with us. And be reassured that we even try to act before the question has been posed, before you have to come to see us, you may wonder "Is our professional aware? Is our professional really involved? Has he observed the student in question?" So often we can go and talk to the professional before I taking an action. So bear in mind that the 
professionals and specialists are there to support you. [M3_SA_S2]

The analysis of pedagogical situations shows that support is sometimes offered on a daily basis in order to prepare students for new class experiences.

If I have done things to intervene at this level... Well for sure, I have a word to say each time, by saying it is not acceptable, that it is not the right moment. [...] and sometimes I will even seek help from the group. Faced to a certain situation, what could we have done instead? I also try to be in prevention mode, for example we will watch a movie, so I judge what we can do and what we cannot do, can we risk doing such an activity, what can we allow ourselves to do or not to do. [M3_SA_S1]

\subsection{Analysis of pedagogical situations to enhance the collaboration level}

It is worth noting that the meetings to analyze practices were held at the request of the participants in our study. When the research team offered them some training, they replied that they already had the expertise in their school that they would rather we analyze pedagogical situations together. At the end of the school year, the personnel mentioned the benefits of having implemented these situational analyses, how they had helped them to better collaborate during the integrating of a student into the regular classroom:

I will say it over and over again, the practice we are doing, this, from the very first time we met, I find it so formative. It's fun, we talk! And we talk a lot. We discuss about real things, the administration is among us and we say what we really think. We are together to find a solution, to find something that might help! Yes, we get involved ... We try to understand better the integration, and I think it's a really, really, a great start. We listen to each other, we talk to each other, and we react. We lay our hands on the problem! For real! It's something that moves us. I really enjoyed it. [M3_SA2_S2]

The personnel also mentioned the relevance of bringing up situations they had really experienced.
This made the exchanges much more significant for them.

$$
\begin{aligned}
& \text { We talk about facts..., when we } \\
& \text { analyzed a situation about my student } \\
& \text { in a meeting, it was significant, } \\
& \text { because we talked about my student. } \\
& \text { [M3_SA_S2] }
\end{aligned}
$$

School 2 staff mentioned the relevance of analyzing situations from the very beginning of the integration planning process as this had allowed them to share everyone's apprehensions in order to then coconstruct new practices taking them into account:

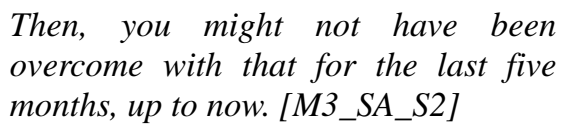

\section{Discussion}

Previous studies had already demonstrated that collaboration among all school staff had a positive effect on students' success [13] [14] and on the integration of students with special needs [12]. The results of this study show that school personnel wish to properly plan the organisation of the integration so that perceptions remain positive, or even become positive among those regular class teachers who may still be reluctant. It can also be observed that the obstacles encountered or anticipated, presented in the meetings, relate specifically to the above mentioned perceptions. Analyzing the situations in groups during the meetings provided useful insights while it allowed them to re-examine and redefine their practices together. These exchanges among all the personnel could contribute to promote the inclusion of students with disabilities or special needs by reducing barriers, generating positive perceptions and creating a culture of openness towards inclusion.

Our results show that the participants are striving to constantly create educational conditions that place the integrated students in the most appropriate environment so that they can be successful in their academic pursuits. They also want the transition to be perceived positively by all those involved, both school staff and students. Some of the topics identified during the meetings as factors and actions that could be facilitators in successful integration were: having every year community sensitization days focusing on integration, planning progressive integration activities leading to full inclusion -a partial integration at first, progressing towards a full inclusion-; offering training to ordinary class teachers, as well as having professionals and experts available to provide guidance whenever necessary. 
Nevertheless, we have observed a lack of time to thoroughly prepare the integration as well as the need for more formal meetings to better plan and organize the transition towards their introduction in the regular classroom. At the beginning of this project, following the research team's proposal of half-day trainings, our participants explained to us that they already had the knowledge at hand, in the school and the school board, but the problem was that they did not have enough time to share their knowledge, their expertise, and to exchange with each other about situations they had experienced or anticipated during an integration.

Although the school board offers training to the schools and school personnel and that it has professionals to support teachers, the participants in our study indicated that some of their colleagues are still reluctant to integrate students with disabilities or special needs into their classes. Another concern that was also mentioned during the meetings was the fact that they felt the integration of special needs students was an additional and daunting task to their already full agendas [25] [26].

Given the great freedom in the organization of educational services in Quebec schools [9], we note that the school principal's involvement and leadership, his desire to promote integration and to take actions that will facilitate the transition to the regular class are essential conditions [27]. Notwithstanding the initial reluctance, once integration succeeds, it does not only benefits the student, but it also benefits the entire class, as it was pointed out by a regular class teacher who participated in our study. By focusing on finding a collective solution to individual learning needs [28], the school is taking a step towards the inclusion of all students.

Planning the number of students per class, the physical space, the support, the continuum of educational services leading to inclusion and, above all, allotting time for expertise sharing and cooperation are the most significant elements that emerged from our results as conditions favouring collaboration and the organization of educational services for all.

\section{Conclusion}

Research findings provide a better understanding of the questionings, the apprehensions, the time needed for planning, and the course of actions proposed by the school personnel that would better support and accompany the teachers and the students during the transition from special to regular classes. It also helped us understand the challenges involved in the organization of educational services.
During one of the situational analysis, the 'narrator' mentioned having difficulty choosing a situation to present. Finally, this person chose to state his negative perception regarding the integration of students with special needs into his regular class. During the 'description of the situation', the first stage of the process, this teacher was able to express all his questionings and name his needs. Putting his thoughts into words opened up the discussion during the group analysis phase. Having understood the needs the group tried to respond, clarify, and explain them. In this sense, the situational analysis procedure represents a collaboration device that has enabled the personnel of this school to better understand the needs and find ways to support inclusive education.

\subsection{Implications}

In school settings, these results will help inform and train, during the initial and continuing education, school personnel (regular class teachers, special class teachers, special education technicians, school principals) vis-à-vis these situation analysis tools. This new knowledge on the organization of educational services could contribute to students' schooling in an inclusive setting or to reintroduce students progressively into regular classes so that they eventually obtain a diploma or qualification.

During the second year of the project, elementary school teachers will be invited to continue the collaboration procedure towards the integration of all students into regular classes. The school personnel will be invited to group interviews aiming to monitor and document all the activities, strategies, and procedures put in place to contribute to the school success of special needs students.

Finally, collaboration with a view to organize and coordinate educational services that help students with special needs succeed cannot be attained without a better knowledge and understanding of the challenges faced by those who implement them. It is our hope that this study satisfies this need for knowledge and helps enhance collaboration to promote inclusive education.

\section{References}

[1] Thomazet, S. (2008) 'L'intégration a des limites, pas l'école inclusive!', Revue des sciences de l'éducation 34(1), pp. 123-139.

[2] CSE. (2016) Rapport sur l'état et les besoins de l'éducation 2014-2016.Québec :Gouvernement du Québec. [3] Beauregard, F. \& Trépanier, N. (2010) 'Le concept d'intégration scolaire...mais où donc se situe l'inclusion?' in N. Trépanier et M. Paré (dir.), Des modèles de service pour favoriser l'intégration scolaire (pp. 31-56). Québec: Presses de l’Université du Québec. 
[4] Commission des droits de la personne. (2018) Le respect des droits des élèves HDAA et l'organisation des services éducatifs dans le réseau scolaire québécois: une étude systémique. Québec.

[5] MEQ. (1999) Politique de l'adaptation scolaire. Québec: Gouvernement du Québec.

[6] Ministère de l'Éducation, du Loisir et du Sport. (2007) L'organisation des services éducatifs aux élèves à risque et aux élèves handicapés ou en difficulté d'adaptation ou d'apprentissage. Québec: Gouvernement du Québec.

[7] Ministère de l'Éducation du Loisir et du Sport. (2014) Rapport du comité d'experts sur le financement, l'administration, la gestion et la gouvernance des commissions scolaires. Québec:Gouvernement du Québec.

[8] Gaudreau, L., Legault, F., Brodeur, M., Hurteau, M., Dunberry, A., Séguin, S.P., Legendre, R. (2008) Rapport d'évaluation de l'application de la Politique de l'adaptation scolaire. Montréal: Université du Québec à Montréal [9] Gaudreau, L. (2010) 'Comment les commissions scolaires québécoises procèdent-elles pour que leurs écoles offrent des services aux élèves handicapés ou en difficulté d'adaptation ou d'apprentissage?' in N. Trépanier \& M. Paré (dir.). Des modèles de service pour favoriser l'intégration scolaire, (pp.5-30). Québec: Presses de l'Université du Québec.

[10] Tremblay, P. (2015) 'Inclusion scolaire et transformation des dispositifs de scolarisation des élèves à besoins spécifiques.' La nouvelle revue de l'adaptation et de la scolarisation 2 (70-71), pp.51-65.

[11] Ministère de l'Éducation, du Loisir et du Sport (2012) Gestion du plan d'intervention. Québec: Gouvernement du Québec.

[12] Bélanger, S. (2006) 'Condition favorisant l'inclusion scolaire,' in Dionne C. et Rousseau N. (dir.), Transformation des pratiques éducatives (pp.63-90). Québec: Presses de l'Université du Québec.

[13] Lapointe, J.R. \& Dion, J. (2015) 'Description d'un processus de théorisation portant sur les conditions de réussite d'une expérience d'inclusion vécue par des élèves en troubles d'apprentissage : pratiques éducatives, attitudes parentales et éléments contextuels.' Approches inductives: Travail intellectuel et construction des connaissances 2(1), 2015, pp. 68-91.

[14] Goddard, Y., Goddard, M. \& Tschannen-Moran, M. (2007) 'A theoretical and empirical investigation of teacher collaboration for school improvement and student achievement in public elementary schools'. Teachers College Record 109(4), pp. 877-896.

[15] Gladstone, C. (2005) 'The search for a model of effective inclusive practice through the young enterprise scheme.' British Journal of Special Education 32(1), pp. 42-47.

[16] Tétreault, S., Beaupré, P., Carrière, M., Freeman, A., Gascon, H. \& Marier Deschênes, P. (2012) 'Déficience, scolarité, parentalité: Comment s'organise la complémentarité des services?' Revue francophone de la déficience intellectuelle 23, pp. 5-12.

[17] Smith, J. S.,Anderson, J. A. \& Abell, A. K. (2008) 'Preliminary evaluation of the full-purpose partnership schoolwide model.' Preventing School Failure 53(1), pp. 28-38.

[18] Dubé, F., Ouellet, C., Moldoveanu, M., Gadbois, M.E. \& Paviel, M.J. (2016) 'Education Organization Models that Enhance the Success of Students with Special Needs.' International Journal of Technology and Inclusive Education 3(1), pp.769-775.
[19] Portelance, L, Cécilia B. \& Pharand, J. (2011) La collaboration dans le milieu de l'éducation. Québec: Presses de l'Université du Québec.

[20] Mitra, S. (2010) Beliefs and practices of elementary school principals regarding collaboration between general and special education staff (doctoral thesis). Northern Illinois University.

[21] Paré, M. \& Trépanier, N. (2010) 'La consultation en milieu scolaire', in N. Trépanier \& M. Paré (dir.) Des modèles de service pour favoriser l'intégration scolaire, (pp.79-98). Québec : Presses de l'université du Québec.

[22] Grossmann, S. (2009) 'Les dispositifs groupaux d'analyse des pratiques au service du développement professionnel des enseignants. Quelles analyses? Quelles pratiques? Quel professionnel?' Canadian Journal of Education, 32(4), pp.764-796.

[23] Brookfield, S. (1995) Becoming a critically reflective teacher. San Francisco : Jossey-Bass.

[24] Gadbois, M.-E. (2015) Adaptation d'un protocole pour favoriser la collaboration dans le cas d'une intégration partielle d'un élève ayant un trouble du spectre de l'autisme à l'école primaire. (Rapport d'activités et projet d'intervention). Université du Québec à Montréal.

[25] Doudin, P. A., Curchod-Ruedi, D. \& Lafortune, L. (2010). 'Inclusion et santé des enseignants et enseignantes: facteurs de risque et de protection.' in N. Rousseau (dir.), $\mathrm{La}$ pédagogie de l'inclusion: pistes d'action pour apprendre tous ensemble (pp. 425-446).Québec: Presses de l'Université du Québec.

[26] Elhoweris, H. \& Alsheikh, N. (2006). Teachers' attitudes towards inclusion.' International Journal of Special Education 21(1), pp.115-117.

[27] Rousseau, N., Prud'homme, L.\& Vienneau, R. (2015). 'C'est mon école à moi aussi...Les caractéristiques essentielles de l'école inclusive,' in Rousseau, N. (dir.) La pédagogie de l'inclusion scolaire. Un défi ambitieux et stimulant. (pp. 5-48). Québec: Presses de l'Université du Québec.

[28] CSE. (2017) Pour une école riche de tous ses élèves. $\mathrm{S}$ 'adapter à la diversité des élèves, de la maternelle à la $5 \mathrm{e}$ année du secondaire. Québec: Gouvernement du Québec.

\section{Acknowledgements}

We wish to thank the Ministry of Education and Higher Education of Quebec. This study was conducted thanks to their financial support as part of a special education partnership project. 